\title{
Bilateral fractures of femoral neck in patients with moderate renal failure receiving fluoride for spinal osteoporosis
}

\author{
J C GERSTER, S A CHARHON, P JAEGER, G BOIVIN, D BRIANCON, A ROSTAN, \\ C A BAUD, P J MEUNIER
}

\begin{abstract}
Two patients with moderate renal failure sustained spontaneous bilateral hip fractures during treatment with fluoride, calcium, and vitamin $D$ for osteoporosis. They had been taking sodium fluoride $(40-60 \mathrm{mg} / \mathrm{day})$ for 11 and 21 months, respectively. Histological examination of a specimen of the bone showed severe fluorosis in the first case, and quantitative analysis of bone showed osteomalacia and skeletal fluorosis in the other case. These abnormalities were considered to be the consequence of excessive retention of fluoride due to renal insufficiency.

As bilateral femoral neck fractures are very rare these data suggest a causal link between fractures and fluoride in patients with renal failure. Thus fluoride should be given at a lower dosage, if at all, to patients with even mild renal failure.
\end{abstract}

\section{Introduction}

Fluoride, combined with calcium and vitamin $\mathrm{D}$ is effective in preventing new vertebral crush fractures not only in primary ${ }^{1}$ but also in corticosteroid induced osteoporosis. ${ }^{2}{ }^{3}$ Fractures of long bones have been described, however, during fluoride treatment, and 13 cases of fracture of the femoral neck, none of them bilateral, have been reported; the cause and effect relation has not been clearly established. ${ }^{4-6}$ We report on two patients with osteoporosis in whom bilateral hip fractures occurred spontaneously after 11 and 21 months of treatment with fluoride; the two patients suffered from moderate chronic renal insufficiency.

Rheumatology and Rehabilitation Centre, University Hospital CHUV-1011 Lausanne, Switzerland

J C GERSTER, MD, consultant rheumatologist

A ROSTAN, MD, senior registrar in rheumatology

INSERM Unité 234, Faculté A Carrel, 69008 Lyons, and Clinique de Fhumatologie, Pavillon E, Hôpital Ed Herriot, 69003 Lyons,

$S$ A CHARHON, MD, research associate, INSERM

$D$ BRIANCON, $M D$, senior registrar in rheumatology

P J MEUNIER, professor of medicine and consultant in rheumatology

Department of Internal Medicine, University Hospital, Lausanne, Switzerland

$P$ JAEGER, $M D$, senior resident in internal medicine

Institute of Morphology, University Medical Centre, Geneva, Switzerland

G BOIVIN, PHD, research associate

C A BAUD, MD, professor of morphology

Correspondence to: Dr J C Gerster.

\section{Case reports}

CASE 1

The patient, a 69 year old woman, had suffered from seropositive nodular rheumatoid arthritis since the age of 41 ; she had been receiving steroids (prednisone $5 \mathrm{mg}$ daily) since the age of 55 . At age 66 chronic pyelonephritis and mild hypertension had been diagnosed. Spontaneous vertebral crush fractures (L2 and 3) occurred when she was 68 .

At that time the serum concentration of calcium was $2.29 \mathrm{mmol} / \mathrm{l}$ $(9.2 \mathrm{mg} / 100 \mathrm{ml})$ and of phosphate $1.6 \mathrm{mmol} / 1(5.0 \mathrm{mg} / 100 \mathrm{ml})$, and alkaline phosphatase activity was $35 \mathrm{IU} / 1$ (normal 17-30 IU/1). Serum creatinine concentration was $230 \mu \mathrm{mol} / 1(2.6 \mathrm{mg} / 100 \mathrm{ml})$ and creatinine clearance $18.5 \mathrm{ml} / \mathrm{min}$. There was no proteinuria or casts, and urine cultures were sterile. Urinary excretion of hydroxyproline was 33 $\mu \mathrm{mol} / 24 \mathrm{~h}(4.3 \mathrm{mg} / 24 \mathrm{~h}$ ) (normal $<420 \mu \mathrm{mol} / 24 \mathrm{~h}(<55 \mathrm{mg} / 24 \mathrm{~h})$ ).

In combination with calcium $\left(1 \mathrm{~g}\right.$ daily) and vitamin $\mathrm{D}_{3}(1000 \mathrm{U}$ daily) oral sodium fluoride was prescribed $(60 \mathrm{mg}$ daily during the first three months and then $40 \mathrm{mg}$ daily). After 11 months of treatment she suddenly developed severe pains in both groins. At physical examination mobility of the hips was appreciably reduced but there were no signs of a flare up of the arthritis. Pelvic $x$ ray examination showed bilateral femoral neck fracture; there was also bilateral acetabular protrusion. At this time serum calcium concentration was 2.03 $\mathrm{mmol} / 1(8.1 \mathrm{mg} / 100 \mathrm{ml})$, serum phosphate concentration $1.2 \mathrm{mmol} / 1$ $(3.7 \mathrm{mg} / 100 \mathrm{ml})$, creatinine concentration $250 \mu \mathrm{mol} / 1(2.8 \mathrm{mg} / 100 \mathrm{ml})$, and alkaline phosphatase activity $73 \mathrm{IU} / \mathrm{l}$. Plasma parathyroid hormone concentration was $0.22 \mathrm{ng} / \mathrm{ml}$ (normal $<0.15 \mathrm{ng} / \mathrm{ml}$, carboxyterminal assay) and 25-hydroxy vitamin D concentration $57 \mathrm{nmol} / 1$ $(22 \cdot 8 \mathrm{ng} / \mathrm{ml}$ ) (normal $23-85 \mathrm{nmol} / 1(9 \cdot 2-34 \cdot 0 \mathrm{ng} / \mathrm{ml})$ ). Total hip replacement with a Charnley prosthesis was performed on both sides.

Histological examination of the femoral head showed no gross excess of unmineralised osteoid; there were signs of osteoarthritis with erosion of cartilage, but no inflammatory signs were detectable in the synovial membrane, although fibrous changes had occurred.

Microradiographs of sections of bone tissue performed according to the method of Baud et $a l^{7}$ showed mottled bone with mottled lacunas and hypervascularity in the compact as well as in the cancellous bone; hypomineralised linear formation defects were also present. These findings strongly suggested severe fluorosis (fig 1).

The bone fluoride content of the surgical specimen was measured on calcinated compact bone with a specific electrode according to the method of McCann. ${ }^{8} \mathrm{~A}$ value of $0.506 \%$ was found which appears to be high compared with the normal value $(0.10(\text { SE } 0.06 \%))^{7}$ and values reported in patients with osteoporosis treated with fluoride $(0 \cdot 21$ to $0 \cdot 40 \%) .^{\circ}$

CASE 2

A 78 year old woman suffered from recent lumbar pain for three weeks before admission. She had a history of hypertension, angina pectoris, and bilateral thrombosis of the popliteal artery. $X$ ray examination of the pelvis showed arterial calcification and signs of bilateral osteoarthrosis of the hips. $X$ ray examination of the spine showed a crush fracture of $\mathrm{L} 1$. Serum calcium concentration was $2.12 \mathrm{mmol} / 1(8.5 \mathrm{mg} / 100 \mathrm{ml})$, serum phosphate concentration $0.87 \mathrm{mmol} / 1(2.7 \mathrm{mg} / 100 \mathrm{ml})$, serum alkaline phosphatase activity $20 \mathrm{IU} / 1$, serum creatinine concentration $133 \mu \mathrm{mol} / 1(1.5 \mathrm{mg} / 100 \mathrm{ml})$, and urinary hydroxyproline excretion $435 \mu \mathrm{mol} / 24 \mathrm{~h}(57 \mathrm{mg} / 24 \mathrm{~h})$. There was no proteinuria.

A transiliac bone biopsy was performed after double labelling with tetracycline, and undecalcified sections were quantitatively analysed according to previously reported methods. ${ }^{10}$ The trabecular bone volume was $12 \cdot 2 \%$ (normal $14 \cdot 8$ (SE $3 \cdot 3$ )), the thickness index of 


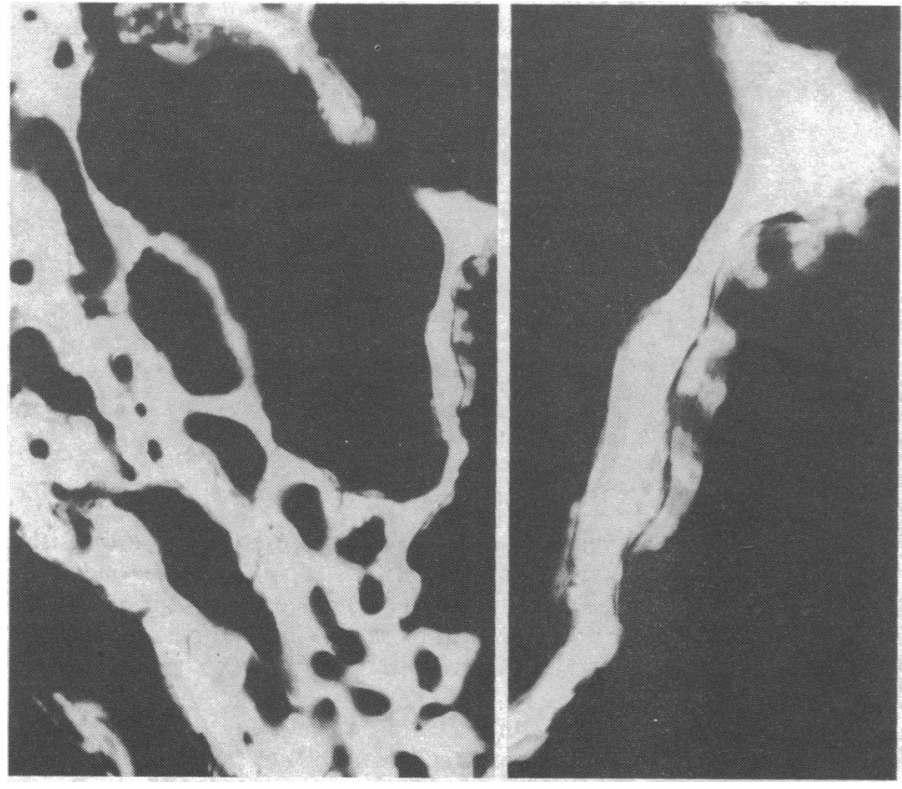

FIG 1-Left: Microradiograph of compact and cancellous bone tissue showing important cortical porosity and mottled aspects of bone tissue (case 1). Right: enlargement of microradiograph on left, showing mottled bone tissue, hypervascularity, and hypomineralised linear formation defects.

osteoid seams was low at 11.4 (normal $17 \cdot 7(4 \cdot 0)$ ), and the rate of mineralisation was normal at $0.79 \mu \mathrm{m} /$ day (normal $0.72(0.12) \mu \mathrm{m} /$ day). Primary osteoporosis was diagnosed.

In combination with calcium $\left(1 \mathrm{~g}\right.$ daily) and vitamin $\mathrm{D}_{2}(8000 \mathrm{U}$ daily) oral sodium fluoride was prescribed at a dose of $50 \mathrm{mg} /$ day. After nine months of treatment another vertebral collapse (T10) was noted. After 15 months of treatment calcium and vitamin D supplementation was withdrawn because of the calcified arteries. After 20 months of treatment she complained of pain in the right hip. $X$ ray examination showed an incomplete fracture of the right femoral neck. At this time the serum creatinine concentration was $142 \mu \mathrm{mol} / 1(1.6$ $\mathrm{mg} / 100 \mathrm{ml}$ ), creatinine clearance $31 \cdot 1 \mathrm{ml} / \mathrm{min}$, serum calcium concen-

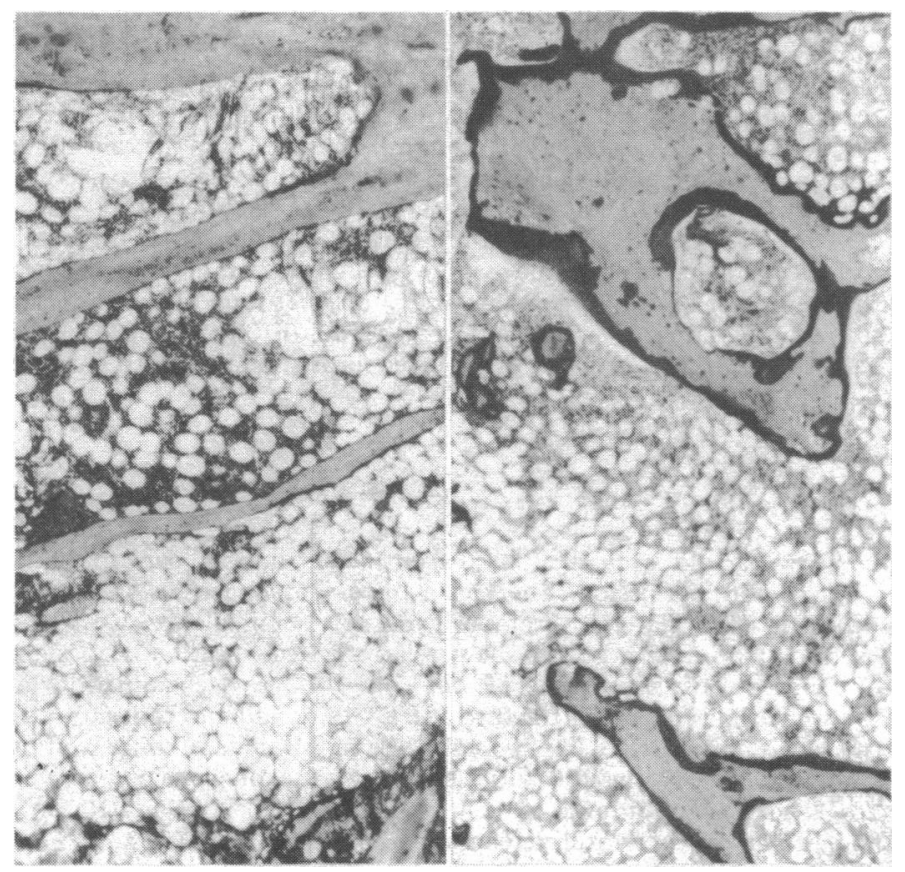

FIG 2-Transiliac bone biopsy specimens (case 2) before (left) and after (right) 20 months of fluoride treatment. Before treatment trabecular atrophy was present but no evidence of osteomalacia. After treatment obvious thick osteoid seams (dark areas) lined the thickened trabeculas. (Solochrome Cyanin stained sections.) tration $2 \cdot 23 \mathrm{mmol} / 1(8.9 \mathrm{mg} / 100 \mathrm{ml})$, serum phosphate concentration $1.09 \mathrm{mmol} / 1(3.4 \mathrm{mg} / 100 \mathrm{ml})$, serum alkaline phosphatase activity 40 IU/l, and parathyroid hormone concentration (carboxyterminal assay) $4.2 \mathrm{mU} / \mathrm{ml}$ (normal $4.0(0.8) \mathrm{mU} / \mathrm{ml}$ ). Urinary hydroxyproline excretion was $235 \mu \mathrm{mol} / 24 \mathrm{~h}(30.8 \mathrm{mg} / 24 \mathrm{~h})$. Serum fluoride concentration was very high $(22 \mu \mathrm{mol} / 1(4.8 \mu \mathrm{g} / 100 \mathrm{ml}))$ on two occasions, and mean urinary fluoride excretion measured on three consecutive days was low $(89.5 \mu \mathrm{mol} / 24 \mathrm{~h})(1.7 \mathrm{mg} / 24 \mathrm{~h}))$ compared with values obtained in 38 patients with osteoporosis treated with fluoride (serum fluoride concentration $10(5.3) \mu \mathrm{mol} / \mathrm{l}(19.0(10 \cdot 1) \mu \mathrm{g} / 100 \mathrm{ml})$ and urinary fluoride excretion $400(270) \mu \mathrm{mol} / 24 \mathrm{~h}(7 \cdot 6(5 \cdot 1) \mathrm{mg} / 24 \mathrm{~h})$ ).

An iliac bone biopsy specimen obtained after double labelling with tetracycline showed osteomalacia with an increased thickness of osteoid seams $(37 \cdot 0)$ and a decreased rate of calcification (less than 0.20 $\mu \mathrm{m} /$ day) (fig 2). Bone fluoride content measured on compact bone of the inner cortex was found to be very high at $0.73 \%$. Microradiographs of bone sections showed signs of severe histological bone fluorosis (mottled bone, hypervascularity, and hypomineralised linear formation defects) comparable with those observed in case 1. Sodium fluoride was thus stopped and replaced with calcium $1 \mathrm{~g}$ daily and vitamin $\mathrm{D}_{2} 8000 \mathrm{U}$ daily. One month later the patient was readmitted with a complete intertrochanteric fracture of the left femur, for which a metallic implant was inserted.

\section{Discussion}

Spontaneous fracture of the femoral neck is a rare finding in primary" as well as in steroid induced osteoporosis. ${ }^{12}$ Fractures of the femoral neck have already been described in patients with osteoporosis receiving fluoride treatment, and have generally been considered to be secondary to fluoride induced osteomalacia. ${ }^{4-6}$ Concurrent administration of calcium and vitamin $\mathrm{D}$, however, prevents or at least minimises defective mineralisation of bone. ${ }^{13}$

In the two cases reported here there was severe skeletal fluorosis as shown by a high bone fluoride content and pronounced histological abnormalities (mottled bone, hypervascularity) on the microradiographs of bone sections. ${ }^{7}$ Furthermore, in case 2 histomorphometric analysis of a transiliac bone biopsy specimen indicated an accumulation of osteoid tissue due to impairment of mineralisation. In this case the serum fluoride concentration was high and urinary fluoride excretion was considerably reduced compared with values obtained in patients with osteoporosis treated with fluoride. ${ }^{2}$

In both these cases the accumulation of sodium fluoride in bone was probably due to reduced renal function. Urinary excretion of fluoride is reduced when creatinine clearance reaches values of about $25 \mathrm{ml} / \mathrm{min} .{ }^{14}$ Cases of skeletal fluorosis have been reported in patients with severe renal failure ${ }^{15} 10$ even with a daily fluoride intake as low as $4 \mathrm{mg} .^{17}$ In patients without renal failure bone fluorosis may occur when the daily dose of ingested sodium fluoride is higher than $60 \mathrm{mg},{ }^{31318}$ and fractures of bones have been described in patients without renal failure but with severe fluorosis induced by treatment with niflumic acid. ${ }^{16}{ }^{19}$ An increased risk of fractures might be due to changes in the mechanical properties of the bone induced by an accumulation of fluoride in the bone tissue, whether or not osteomalacia is present.

The tensile strength of bone in patients with severe fluorosis is decreased, ${ }^{20}{ }^{21}$ and there is an enlargement of periosteocytic lacunar surfaces and excess cortical porosity. ${ }^{7}$ In contrast, bone strength is increased in patients with moderate fluorosis ${ }^{21}$ that is, in those with a sodium fluoride intake of less than $60 \mathrm{mg}$ a day ${ }^{1}$ and normal renal function.

These data show that treatment with fluoride at the generally prescribed dose may induce severe skeletal fluorosis in patients with impaired renal function. Thus before treatment is started renal function should be carefully assessed; the drug should either not be given at all or should be given at a lower dosage to patients with renal failure.

We are grateful to Professor R Lagier who performed the histological examination in case 1 , and to Professor P Burckhardt for his critical review of the manuscript.

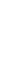

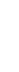

.

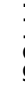

. 


\section{References}

${ }^{1}$ Riggs BL, Seeman E, Hodgson SF, Taves DR, O'Fallon WM. Effect of the fluoride/calcium regimen on vertebral fracture occurrence in postmenopausal osteoporosis. N Engl F Med 1982;306:446-50.

${ }^{2}$ Briancon D, Meunier PJ. Treatment of osteoporosis with fluoride, calcium and vitamin D. Orthop Clin North Am 1981;12:629-48.

${ }^{3}$ Cohen P, Gardner FH. Induction of skeletal fluorosis in two common demineralizing disorders. FAMA 1966;195:962-3.

4 Inkovaara J, Heikinheimo R, Jarvinen K, Kasurinen U, Hanhijarvi H, Iisalo E. Prophylactic fluoride treatment and aged bones. $\mathrm{Br} \mathrm{Med} \mathcal{J}$ 1975 ;iii :73-4.

${ }^{5}$ Riggs BL, Hodgson SF, Hoffman DL, Kelly PJ, Johnson KA, Taves D. Treatment of primary osteoporosis with fluoride and calcium. Clinical tolerance and fracture occurrence. $\mathcal{F} A M A$ 1980;243:446-9.

- Glimet T, Kuntz D, De Vernejoul MC, Ryckewaert A. Fissurations osseuses multiples au cours d'un traitement de l'ostéoporose par le fluorure de sodium. Rev Rhum Mal Osteoartic 1980;47:581.

'Baud CA, Lagier R, Boivin G, Boillat MA. Value of the bone biopsy in the diagnosis of industrial fluorosis. Virchows Arch [Pathol Anat] $1978 ; 380: 283-97$.

"McCann HG. Determination of fluoride in mineralized tissues using the fluoride ion electrode. Arch Oral Biol 1968;13:475-7.

${ }^{9}$ Baud CA, Lagier R, Bang S, Boivin G, Gossi M, Tochon-Danguy HJ. Treatment of osteoporosis with $\mathrm{NaF}$, calcium or/and phosphorus and vitamin $\mathrm{D}$ : histological, morphometric and biophysical study of the bone tissue. In: Courvoisier B, Donath A, Baud CA, eds. Fluoride and bone. Berne: Huber, 1978:290-2.

10 Meunier PJ, Sellami S, Briancon D, Edouard C. Histological heterogeneity of apparently idiopathic osteoporosis. In: De Luca HF, Frost HM, eds. Osteoporosis: recent advances in pathogenesis and treatment. Series. Baltimore: University Park Press, 1981:293-301.
11 Urist MR, Gurvey MS, Fareed DO. Long term observations on aged women with pathologic osteoporosis. In: Barzel US, ed. Osteoporosis. New York: Grune and Stratton, 1970:3-37.

12 Hahn TJ. Corticosteroid-induced osteopenia. Arch Intern Med 1978;138: 882-5.

13 Jowsey J, Riggs BL, Kelly PJ, Hoffmann DL. Effect of combined therapy with sodium fluoride, vitamin $\mathrm{D}$ and calcium in osteoporosis. $A m \mathcal{F}$ Med $1972 ; 53: 43-9$.

14 Schiff $\mathrm{HH}$, Biswanger U. Human urinary fluoride excretion as influenced by renal function impairment. Nephron 1980;26:69-72.

15 Juncos LI, Donadio JV. Renal failure and fluorosis. FAMA 1972;222: 783-5.

${ }^{16}$ Baud CA, Boivin G, Demeurisse C. Drug induced skeletal fluorosis. Fluoride 1982;15:54-6.

17 Spencer H, Kramer L, Gatza C, Norris C, Wiatrowski E, Gandhi VC. Fluoride metabolism in patients with chronic renal failure. Arch Intern Med 1980;140:1331-5.

18 Meunier PJ, Courpron P, Smoller JS, Briancon D. Niflumic acid-induced skeletal fluorosis: iatrogenic disease or therapeutic perspective for osteoporosis. Clin Orthop 1980;148:304-9.

19 Prost A, Boiteau HL, Gaillard F, Hamelin JP, Carlier N, Renac FR. Ostéose fluorée secondaire à un traitement très prolongé par l'acide niflumique dans deux cas de polyarthrite rhumatoïde. Rev Rhum Mal Osteoartic 1978;45:707-16.

${ }^{20}$ Evans FG, Wood JL. Mechanical properties and density of bone in a case of severe endemic fluorosis. Acta Orthop Scand 1976;47:489-95.

${ }^{21}$ Franke J, Runge H, Grau P, Fengler F, Wanka C, Rempel H. Physical properties of fluorosis bone. Acta Orthop Scand 1976;47:20-7.

(Accepted 10 fune 1983)

\section{SHORT REPORTS}

\section{Sickle cell anaemia, oxygen treatment, and anaemic crisis}

Vaso-occlusion by sickled erythrocytes is believed to underlie the major clinical manifestations of sickle cell disease. Since sickling is promoted by deoxygenation in vitro it seems logical and, indeed, it is common practice to administer oxygen to patients with sickle cell disease experiencing acute vaso-occlusive crises. While the danger of even moderate hypoxia and the need for maintaining adequate oxygenation are obvious in these patients the untoward effects of hyperoxygenation are less well appreciated. This report illustrates the danger of overzealous administration of oxygen.

\section{Case report}

A 24 year old black man with sickle cell anaemia was admitted to hospital with an "acute chest syndrome." Sputum and blood samples were obtained for cultures and he was given empirical treatment with penicillin. Later a mycoplasma infection was suspected and erythromycin was added to the treatment. His arterial oxygen pressure $\left(\mathrm{PO}_{2}\right)$ was $9.7 \mathrm{kPa}(73 \mathrm{~mm} \mathrm{Hg})$ so oxygen was given by a nasal cannula at $8 \mathrm{l} / \mathrm{min}$ which raised his $\mathrm{PO}_{2}$ to $15.2 \mathrm{kPa}(114 \mathrm{~mm} \mathrm{Hg})$. His initial packed cell volume was $0.265(26.5 \%)$, reticulocyte count $10 \cdot 6 \%$, lactate dehydrogenase activity $505 \mathrm{IU} / \mathrm{ml}$ and total bilirubin concentration $66.7 \mu \mathrm{mol} / 1(3.9 \mathrm{mg} / 100 \mathrm{ml})$. On the fourth day, as his chest syndrome was rapidly improving, the reticulocyte count acutely decreased to $1.4 \%$ and remained at that figure for the next three days. There was an associated rapid decrease in his packed cell volume to $0.175(17.5 \%)$, the lactate dehydrogenase activity fell to $298 \mathrm{IU} / \mathrm{ml}$, and the total bilirubin concentration to $24 \cdot 0 \mu \mathrm{mol} / 1(1.4 \mathrm{mg} / 100 \mathrm{ml}$ ) (figure). Red cell transfusions were considered but not carried out, and a bone marrow aspiration was contemplated; but during the investigation into the cause of the anaemic crisis we discovered that the patient had been maintained at an arterial $\mathrm{PO}_{2}$ of $>13.3 \mathrm{kPa}(>100 \mathrm{~mm} \mathrm{Hg})$ immediately before and throughout the period of reticulocytopenia. Discontinuation of oxygen administration resulted in a prompt rebound reticulocytosis and a rapid return of the packed cell volume to a steady state. Bacteriological studies and serological test for mycoplasma infection were negative.

\section{Comment}

The temporal relation of the haematological events and the administration of oxygen combined with a lack of evidence for a bacterial or mycoplasmal infection and the rarity of parvovirus infection in this age group ${ }^{1}$ leave an excessive partial pressure of oxygen as the most likely cause of the acute suppression of erythropoiesis. Hypoxia is a strong erythropoietic stimulus-but the erythrosuppressive effect of hyperoxia, though well established, is not widely known. Many years ago experimental administration of high concentrations of oxygen to

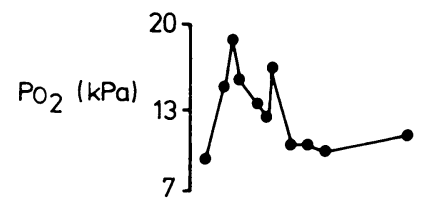

Nasal oxygen $81 / \mathrm{m} \quad \because \because \cdot$

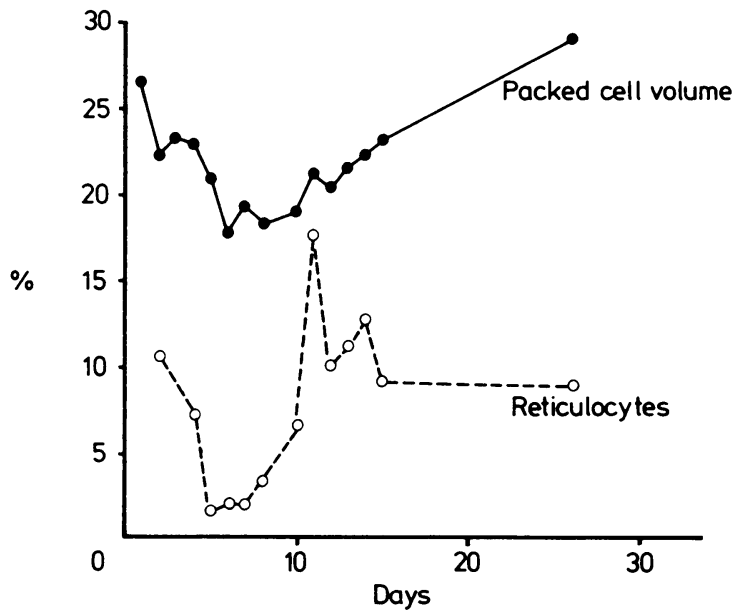

Penicillin Erythromycin

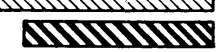

Lactate

dehydrogenase (IU/ml) 505298

Bilirubin (umol/1) $\quad 66.7 \quad 23.9$

540

Changes in haematological and respiratory variables in relation to treatment in patient with sickle cell anaemia.

Conversion: SI to traditional units-Oxygen pressure $\left(\mathrm{PO}_{2}\right): 1 \mathrm{kPa} \approx$ $7.5 \mathrm{~mm} \mathrm{Hg}$. Bilirubin: $1 \mu \mathrm{mol} / 1 \approx 0.06 \mathrm{mg} / 100 \mathrm{ml}$. 